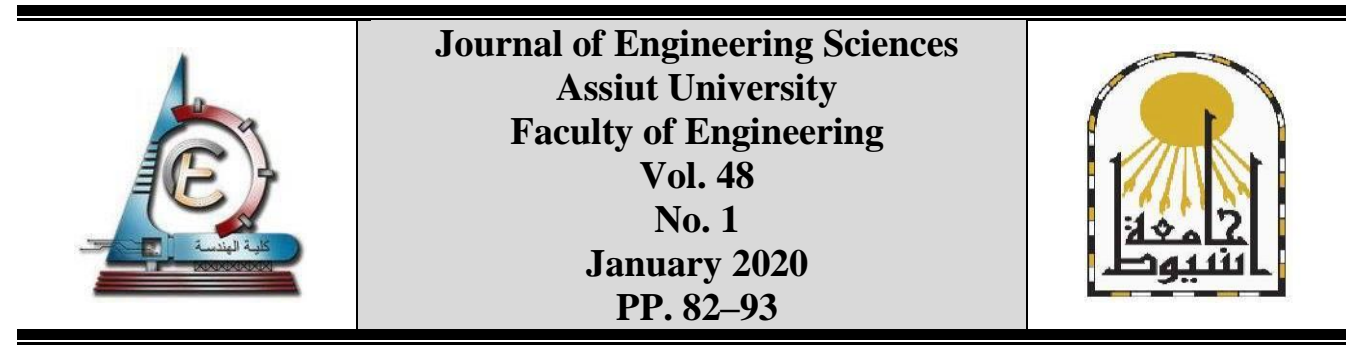

\title{
ANALYTICAL STUDY OF HERITAGE RESIDENTIAL BUILDINGS IN THE CENTRAL REGION OF SAUDI ARABIA
}

\author{
Salma I. Dwidar ${ }^{1} *$, Walaa Metwally ${ }^{2}$, Amal Abbas Abdelsattar ${ }^{3}$ \\ ${ }^{1,2,3}$ Architectural Eng. Depart, Faculty of Engineering, Prince Sultan University, Riyadh, KSA \\ ${ }^{2}$ Architecture Department, Faculty of Fine arts, Alexandria University, Alexandria, Egypt
}

Received 26 June 2019; Accepted 11 July 2019

\begin{abstract}
The architecture of any nation reflects the social and religious concepts of the citizens' lifestyles, as well as the extent to which people in one nation are connected and influenced by other civilisations. The architectural style of the Kingdom of Saudi Arabia (KSA) is not much different from that of the Arabian Peninsula. Saudi architecture has been designed with a consideration for natural factors, such as climate and the environment, and has also been influenced by the human environment, including social and economic factors. The general structure of the urban fabric appears random, in terms of form and layout, but this, in fact, corresponds to certain necessities forced by the local environment.

This study aimed to identify the social and natural environmental characteristics of residential heritage buildings in the central region (Najd area) of the KSA. The factors that have affected these unique residential designs, which are based on adaptations to the natural environment, are highlighted. Based on the study, recommendations are made that can be applied in future architectural projects in the region.
\end{abstract}

Keywords: Heritage Buildings, Natural Environment, Architectural Style, urban Fabric

\section{Introduction}

The popular cultural concept of architectural design in the Kingdom of Saudi Arabia (KSA) goes beyond simple spatial boundaries, being affected by identifying the particular activities, and positive and negative images, that are generated in these spaces.

Space in traditional Saudi society was designed around a common sense of social environmental values, stemming from religious and cultural concepts. As such, the spatial composition of the traditional house is based on fundamental aspects of the nature of its inhabitants, their cultural, religious and social environmental values.

This study is based on the description and analysis of the traditional urban fabric in Saudi Arabia, and specifically the traditional environments represented by Najd, as well as the design of traditional houses, in terms of use and construction, and the impact of the social and climatic environment on their design.

\subsection{Research aims}

This study aimed to identify traditional Saudi climatic and social environmental architectural aspects ,drawn from a descriptive and analytical study, in order to record and preserve these, and use them in designing contemporary Saudi housing that respects the past, present and future. 


\subsection{Research methodology}

The methodology of the study comprised three parts:

1. A theoretical study focused on the historical background of the KSA, as well as general patterns of its traditional architecture. For more detail, a case study was investigated -the central Najd region.

2. An analytical study of the traditional urban fabric and housing, based on social and climatic environmental factors, was performed.

3. Aspects of the traditional structural treatments used in the established housing were examined in order to exploit and further develop these for use in the design of contemporary and future housing in Riyadh in particular, and the area of Najd in general.

\section{Historical background of the KSA}

In this section, the history of the KSA is reviewed, from a geographical and climatic viewpoint, and the factors affecting the general patterns of traditional building are examined:

\subsection{History of Saudi Arabia}

The KSA is located at the core of the Arabian Peninsula. It lies at the intersection of three continents - Africa, Asia and Europe. Its geographic position placed it at the hub of early civilisation, crossed by trade routes that connected Mesopotamia and Egypt, and linked the Greek and Roman Empires with those of India and China [1].

The Qur'an (Koran), the holy book of Islam, was revealed to the Prophet Muhammad in the Arabian urban communities of Mecca and Madina, starting around $610 \mathrm{AD}$. The introduction of the new faith of Islam was of major significance. Inspired by Islam, the Arabs ventured out of Arabia, spreading Islam and the Arabic language. Their immense domain extended from the Atlantic Ocean in the west to Central Asia in the east, encompassing present-day southern Italy, Spain and parts of France.

The Muslim Arab civilisation remained powerful for a long time, in giving strength and advancing human knowledge. The Arabs made broad and unique contributions to science, medicine, optics, astronomy and mathematics. In addition, they introduced the numerical framework - Arabic numerals - to the West.

The history of modern Saudi Arabia starts with Abdul Aziz Al-Saud. The Al-Saud family reigned over much of Arabia in the mid-nineteenth century. At that point, Abdul Aziz was authoritatively pronounced ruler, and the nation was named as the KSA in 1932. Following the discovery of oil in commercial amounts in 1938, there has been rapid economic growth and an ascent in world affairs have ruled the latest time of Saudi Arabia's history [1].

\subsection{Geography of the KSA}

The Arabian Peninsula is almost the same size as Europe or India. It has an area of around 2.24 million $\mathrm{m}^{2}$. Saudi Arabia, with an area of 1,960,582 $\mathrm{m}^{2}$ occupies around 80 percent of the peninsula. It lies between $35^{\circ} \mathrm{E}$ and $55^{\circ} \mathrm{E}$ and $16^{\circ} \mathrm{N}$ and $32^{\circ} \mathrm{N}$. It is surrounded by Jordan, Iraq and Kuwait in the north, the Arabian Gulf and United Arab Emirates in the east, Yemen and Oman in the south, and the Red Sea in the west [1].

The KSA has six major geophysical regions:

1. The Great Rub al-Khali, or Empty Quarter, a sand desert occupying the entire south and southeast;

2. The Najd, a vast, barren plateau in the centre. 
JES, Assiut University, Faculty of Engineering, Vol. 48, No. 1, January 2020, pp. 82-93

3. The Asir region, with mountains rising to a significant height from an arid coastal plain;

4. The Hijaz region alongside the Red Sea;

5. The Eastern Province alongside the Arabian Gulf,; this is the area of rich oil reserves

The desert of Nafud and the northern region along the border with Jordan.

The KSA environment is variable. On the whole, it is generally infertile, with predominantly salt pads, gravel plains and dunes, but also with a couple of lakes or lasting streams. In the south is the Rub Al-Khali (Empty Quarter), the biggest sand desert on the planet. In the southwest, the mountainous Asir territory ascends to more than $3000 \mathrm{~m}$.

The KSA has something like one-quarter of the world's oil reserves, and the oil business rules the economy, broadening the industrial base through the manufacture of, for example, metals, synthetic substances and plastics. Alongside this, grains, dates, organic citrus products and vegetables are grown, and the Bedouins raise camels, sheep, goats and horses [2].

\subsection{The climate of the $K S A$}

The atmosphere is typically hot and exceptionally dry, with high humidity along the coast. The temperatures in the desert can reach $50^{\circ} \mathrm{C}\left(122^{\circ} \mathrm{F}\right)$ by the early afternoon, from June through August. Humidity in the coastal areas may approach $100 \%$ on occasion. Interestingly, the climate in different zones of the country can be consistently mild. Temperatures in the winter in the northern and central regions can drop to below freezing. The Shamal - sand-laden winds from the northern desert - occur regularly in late spring, and can blow for a considerable length of time at 25-30 miles per hour. Precipitation ranges from none at all for as long as 10 years in Rub Al-Khali, to 20 inches every year in the mountains of Asir Province [1].

\subsection{Classification of the KSA according to climatic factors}

The climate in Saudi Arabia is affected by different elements, including temperature, the movement of the sun, humidity, the direction and speed of the wind, and rain.

A simplistic approach can be used to divide it into the following four climatic zones [3]:

- Hot, dry region (Riyadh, Medina, Qassim and Mecca);

- Hot, humid region (Jeddah, Jizan, Yanbu);

- Composite climate zone (Dhahran, Qatif, Khobar and Dammam); and

- Upland (Abha, Taif, Khamis and Mushayt).

\subsection{General styles of regional native architecture}

The Saudi native architecture has been impacted by certain variables, such as climate, culture, the economy and the availability of building materials. The coming together of each of these needs, in physical terms, caused the native style of architecture to evolve. In this way, the buildings can be viewed as a physical solution to the different conditions of a place and the individuals in that place, the solution being provided amicably and under exceptional socioeconomic conditions [1].

Although the cultural conditions are almost the same, and the economies are also similar, differences in building materials and climatic conditions in the various regions of the KSA have resulted in the evolution of distinctly different house types and means of providing shelter from the harsh climate. The main regional styles of native architecture, and their basic analytical descriptions, for the central, eastern, southern and western regions are presented in Figure 1.

Figure 1 illustrates the KSA divided according to geographical factors, as follows [2]: 
- Central region (Riyadh and Qasim - known as Najd);

- Western region (Mecca, Medina, Jeddah and Ta'if);

- Eastern region (Dammam, Khobar and Dhahran);

- Southern region (Jazan, Asir, Najran and Baha); and

- Northern region (Tabuk, Ha'il and Al-Jouf).
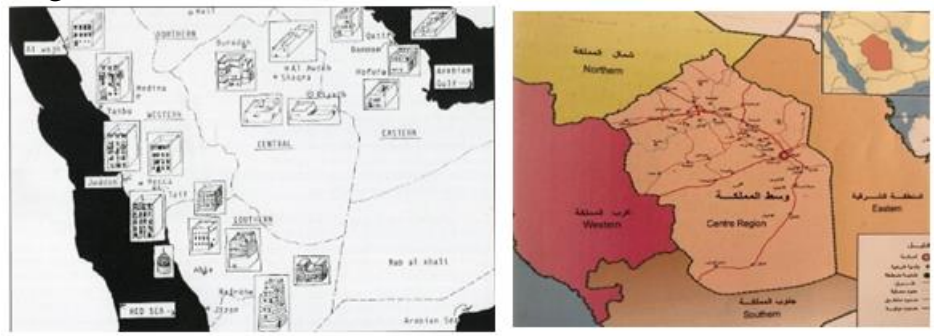

Fig. 1. Different styles of native architecture in different regions of the KSA [2]

Fig. 2. Central region of the KSA [1]

\section{Historical background of the central region (Najd)}

As shown in Figure 2, the central region of the KSA comprises the administrative province of Riyadh, along with Quasim and Hayel.

\subsection{Geographic factors of the central region}

The geographic factors are not affected by any of the neighboring civilisations. This region occupies around $19 \%$ of the area of the KSA. The surface of the region varies, and includes mountains, plateaus and plains, which are dominated by the occurrence of highlands. This is known as the Najd region.

The central region embraces most of the agricultural areas in the KSA. Qasim produces $48 \%$ of the wheat and has $23 \%$ of the agriculture land in the country [1].

\subsection{Climatic factors of the central region}

The climate is hot and dry in the summer (Figure 3), when the temperature rises to $45^{\circ} \mathrm{C}$, while in the winter, it is below $10-20^{\circ} \mathrm{C}$, with light rain. Spring is the season of the main rainfall [1] [16].
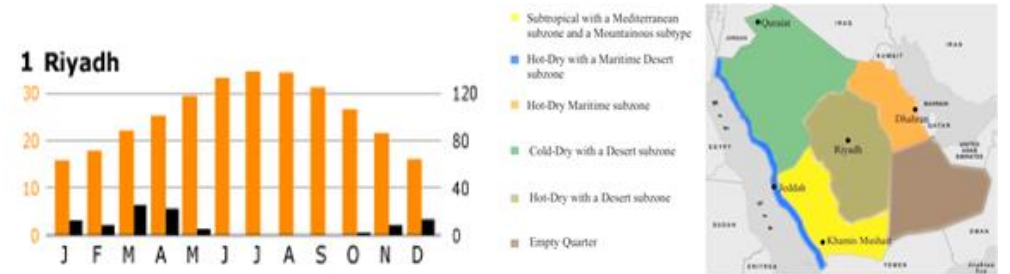

Fig. 3. Climate in the central region of the KSA [3]

\section{Influence of social and climatic environmental factors on the design of traditional housing in the central region}

Social and climatic environmental factors had a powerful influence on the design of traditional buildings in the KSA. These factors greatly affected the general form of the city, urban planning and architectural design.

4.1. Impact of social environmental factors on the design of traditional urban planning and housing in the central region 


\subsubsection{Urban planning}

The shaping of the physical, traditional Saudi environment was influenced by religious, cultural and socioeconomic contexts more than natural environmental factors. As shown in Figures 4 and 5, the main mosque was located in the main square of the city. The market was located adjacent to the mosque. All the main roads intersected and led to the main mosque [1].

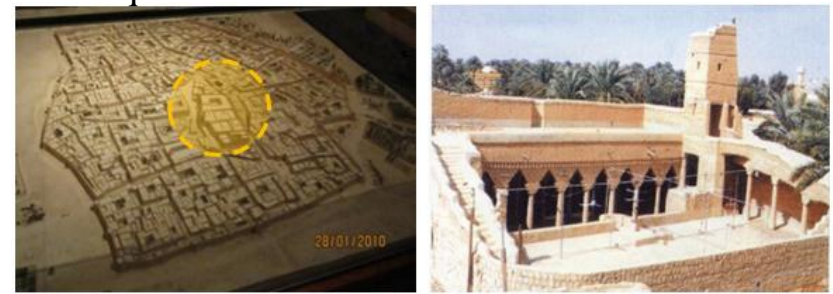

Fig. 4. The mosque was used as the focal point in Riyadh city

Fig. 5. The main mosque in Qassim city [1]

As shown in Figure 6, the main mosque was located in the main square of old Riyadh city. When the city is extended, it will contain several main squares, each with a large mosque and adjacent market (Figure 7).

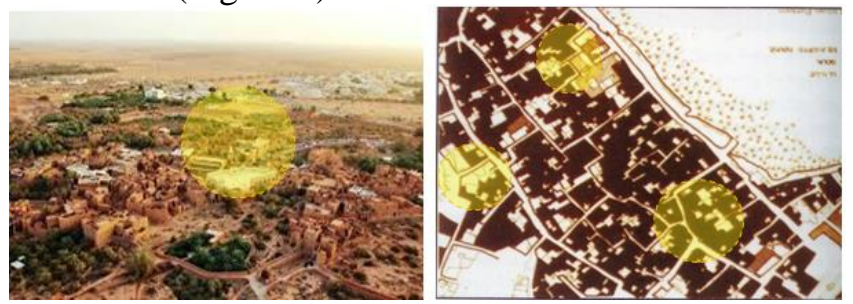

Fig. 6. The main square in old Riyadh city [1]

Fig. 7. The extended city, with several squares [1]

As shown in Figures 8 and 9, the design of the public spaces and buildings in Riyadh, vertically and horizontally, developed on a human scale, as the human was viewed as the main component of the integrated social system.

The design of the traditional buildings was characterised by simplistic and homogeneous architectural elements. Quarters were only used in the houses of rich people. All the houses are almost identical in all elements, such as the shape of the building, the material, height and even the exterior decoration [4].

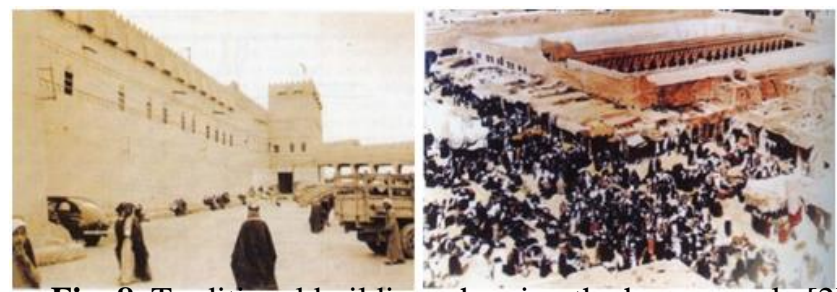

Fig. 8. Traditional building, showing the human scale [2]

Fig. 9. The traditional buildings were characterised by simplistic architecture [2]

\subsubsection{Residential buildings}

The traditional house exhibits a great concern for privacy and the need for defence. This is reflected by the exterior of the house, which forms a solid wall with small, high openings that prevent intrusion into the private life of the household [5]. Each house contains one or 
more small openings above the entry, which provides a view of the street, so the women of the house can see visitors without being seen (Figure 10).

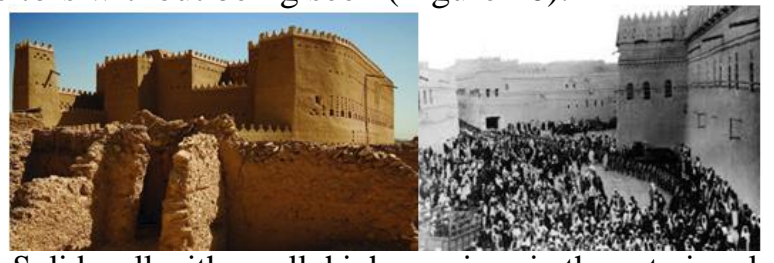

Fig. 10. Solid wall with small, high openings in the exterior elevation [14]

As shown in Figure 11, the traditional house mainly consists of two sections, one for the men, and the other for the family, each with independent access from the outside [2]. It contains two courtyards, one for each section - the courtyard connected to the entrance wass for the men's section, and the other was connected to a women's sitting room as the women's section. The courtyard was designed carefully to ensure privacy by using a short corridor or screening wall, which acts as a space filter, so that visitors cannot see into the house, even if the door is left open.
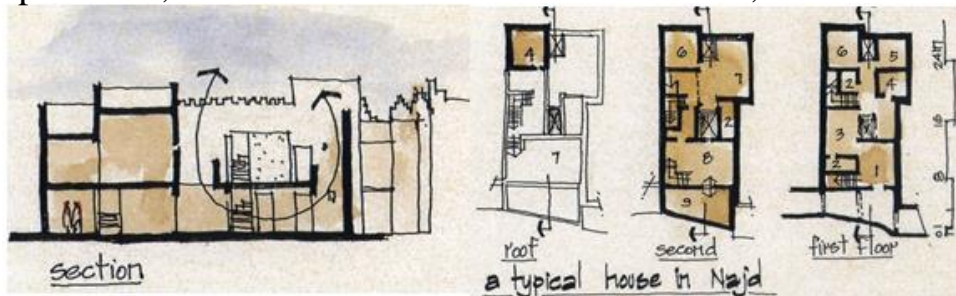

Fig. 11. A typical house from the central region, showing the section (left) and plans for each floor (right) [2]

The house contains two stairs, one for each section. It has several small openings, which are usually close to the ceiling for ventilation. The main entrance from the street leads to a foyer and a twisted entry to the courtyard so as to maintain the privacy of the family. Such houses mainly consist of two floors. Figures 12-14 show different views of a traditional house. The figures illustrate that the men's section occupies one-third to one-half of the house space, and encompasses the main entrance, a traditional fireplace for making coffee, an iwan for guests, corridors leading to the dome in the family section and a staircase. The men's section is attached to an open courtyard. As shown in Figures 12-14, the family section contains the dome - a lobby that interconnects the different parts of the house — and a sleeping and living room, a courtyard, a kitchen, a staircase, storage space and the toilets.
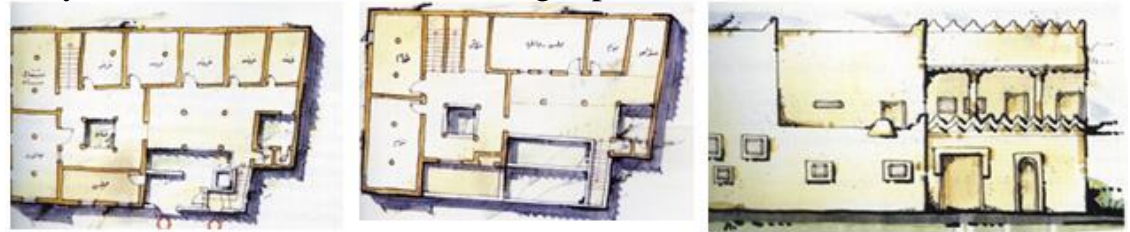

Fig. 12. Ground-floor plan [1]

Fig. 13. First-floor plan for a typical Najd house [1]

Fig. 14. Front elevation of a heritage house [1]

\subsection{Influence of climatic environmental factors on the design of traditional} urban planning and housing in the central region

The central region has its own planning and architectural style in the traditional setting. The structure is compact and solid, and with lack of open spaces in the residential quarters because of the hot climate of the region. The buildings are oriented away from the street, towards the inner courtyards. Corridors are narrow, the openings in the walls are small, and 
the buildings are tightly grouped. The buildings are of almost similar height, to maximise shade and minimise exposure to weathering.

The hot, dry climate of the central region has influenced the building design as reflected in the location of all of the elements of the house around an inner courtyard, and the reduction, or lack, of external openings. Such a design relies on an exposed internal courtyard to provide light, and to modify the air to ensure thermal stability inside the house. The walls are built of stone or clay (local natural materials), and are thick, whereas the rooves are made of palm trunks, covered with broken stones and mud [1].

\subsubsection{Urban planning}

The urban pattern is compact and solid, with buildings tightly grouped and building blocks attached, and a lack of open spaces in the residential quarters in response to the hot, arid climate of the region. As shown in Figures 15 and 16, the planning of native Najd villages ensured deep shadows for the residents, even in the midday hours. Figure 17 indicates that the buildings were oriented away from the street, towards the inside and an inner courtyard, with narrow corridors and small wall openings.

The traditional houses have a small courtyard in the middle, around which the rooms were laid out. Some rooms in the houses bridge the street, and many have small openings in the walls to facilitate air movement to provide comfort for the residents and whilst providing a screening to the street.
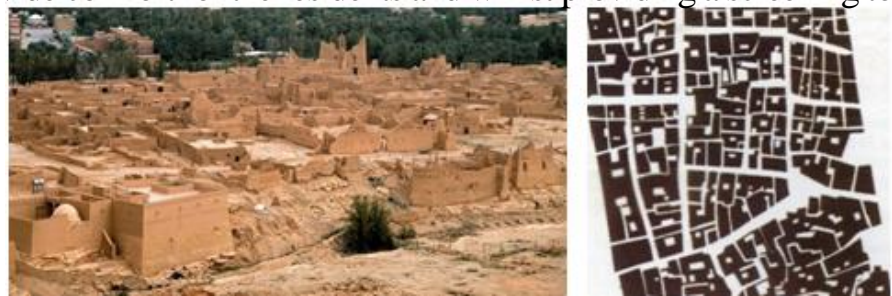

Fig. 15. Design of the urban structure in the central region [1]

Fig. 16. Contact of the urban plan for the central region Narrow streets in the urban plan [1]

\subsubsection{Residential buildings}

Here, we analyse the Saudi housing in the central region, and identify the elements that achieve compatibility with the climatic conditions of the region, through thermal comfort, the use of an inner courtyard, narrow windows and the thickness of the outer walls.[10]

\subsection{The courtyard [6]}

In the traditional architecture of arid lands, from western Africa to central Asia, the most efficient climatic moderator is the courtyard. It traps cool air at night that dissipates gradually during the day into the surrounding rooms and spaces, as indicated in Figure 17, In the typical courtyard house, the open space is almost altogether closed off from the external environment at ground level, which provides a direct shield from the heat and also produces shadow [7]. 


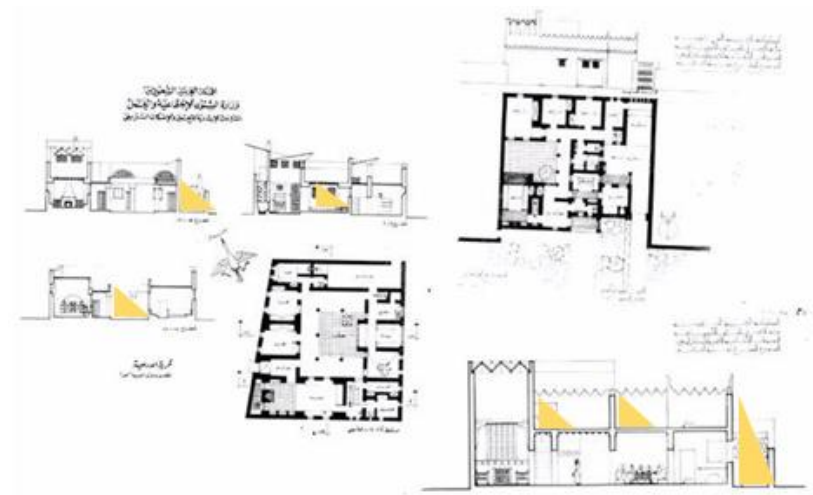

Fig. 17. Shade in the inner courtyard in a KSA central region house [4]

According to aerodynamics, a breeze blowing over such a house will not enter the courtyard, but it will circulate the air inside it [8]. Wind passing overhead creates a lowpressure zone in the courtyard. The low pressure is counteracted by airflow through the rooms and into the courtyard, created by well-placed openings and by the courtyard's chimney effect. The courtyard hold the cooled air that settles there, and that air also moves into the rooms and walls, cooling the house [9] (Figures 18, 19). At night, the patio and rooftop act as a cool air sink; at midday, as the sun warms the courtyard, the warm air rises, helped by the impact of the fireplace, and it pulls a breeze through the rooms, while in the evening, the courtyard and building that held the heat during the day, at that point cool as the night air cools. [14]

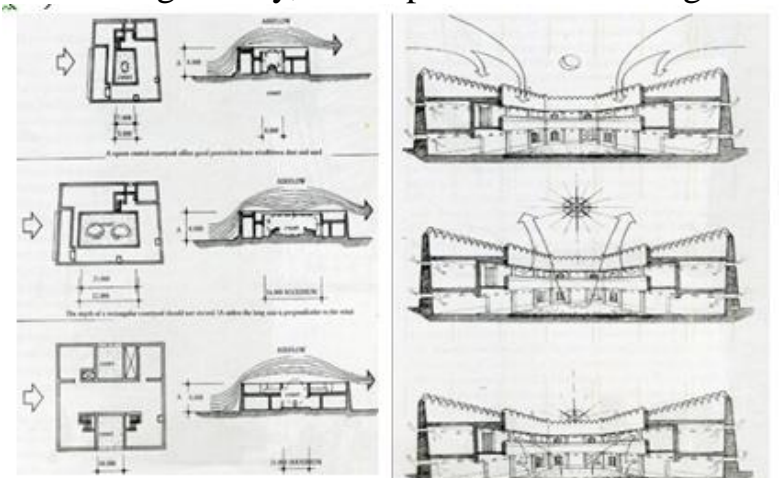

Fig. 18. The effect of dust-laden winds on the inner courtyard [12]

Fig. 19. The effect of temperature on the inner courtyard [12]

\subsection{Landscaping}

Trees and other plants are used, both in the courtyard and around the house, to clean the air and enhance its moisture content. In almost the all traditional examples observed for this study, the courtyard is the central feature. There are various ways to deal with the courtyard as a function of the open s pace in a house (Figure 20).

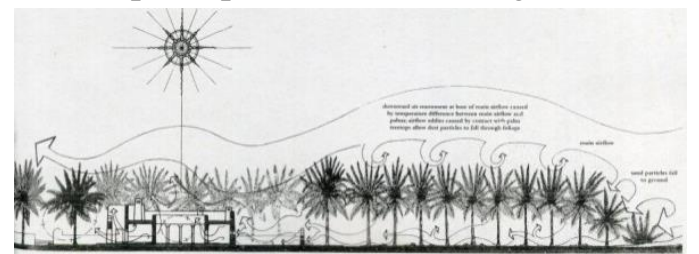

Fig. 20. General section of a typical traditional house, showing how the small openings facilitate air movement [12] 


\subsection{Small openings}

The openings in traditional houses are generally small. They provide much-needed ventilation, facilitate air movement and allow in enough light to the interior to allow people to go about their daily business and stay cool all day long in the summer heat, and also provide a view of the street [11] (Figure 21).

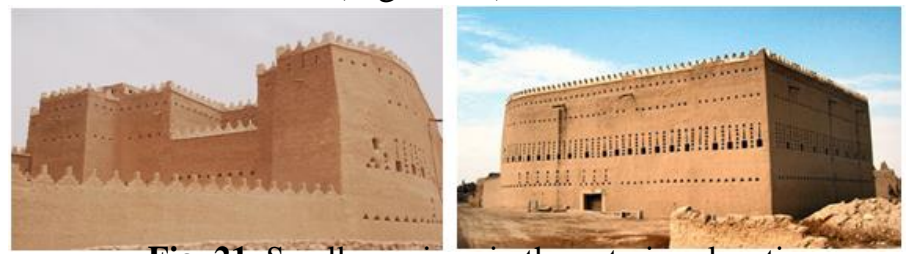

Fig. 21. Small openings in the exterior elevation

\subsection{Walls [12]}

Mud is the principal traditional material of construction in the central region. The insulating qualities of mud make it an appropriate building material for this environment (Figure 22). The walls are thick, providing thermal mass to maintain a consistent interior temperature. As shown in Figure 23, the thick exterior walls typically measure from $100 \mathrm{~cm}$ at the base to $45 \mathrm{~cm}$ at the top. The walls are often shared in denser developments; this helps the houses shade one another, reducing their exposure to solar heat and glare (Figure 24).
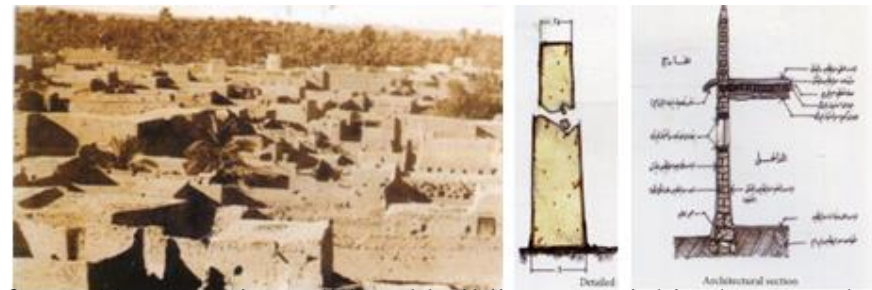

Fig. 22. Mud is the main traditional building material in the central region [11]

Fig. 23. Detailed section through an external wall [1]

Fig. 24. Architectural section of an external wall [1]

\subsection{Materials}

\subsubsection{Mud}

Traditional buildings were adapted to use local media as the main construction materials, which are thus harmless to the environment. In Najd, mud was the main construction material. Consequently, the architecture of the region has been termed 'muddy architecture'. [15] Mud was commonly used for the following reasons:

- It is available and accessible, low cost and easy to work with; and

- It provides thermal insulation through its ability to withstand, and protect the inhabitants from, the extreme and changing climatic effects inherent in the desert environment of the region.

Mud has been obtained from different locations, including the lowlands where the floodwaters settled, where the valleys and agricultural areas are (Figures 23, 24).

\subsubsection{Wood}

Certain types of vegetation are used in the roofing and doorways that are provided by the surrounding environment, such as straw, which is mixed with the mud, and tulips and palm branches in the rooves, columns and around the doors and windows (Figure 25). 

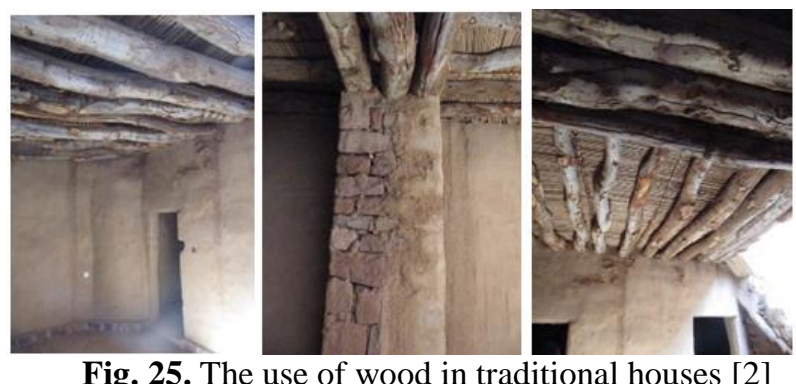

Fig. 25. The use of wood in traditional houses [2]

\subsubsection{Stones}

Soft stones have also been used in traditional buildings for ease of construction. Soft stones are sourced from the highlands. Another type of stone - a red and blue basalt granite - has also been used because of its availability in areas close to the building sites. Due to the unavailability of stones, these were used in specific parts of the building construction, such as the foundations of the walls and the entrance to the building [13].

Stones were also used to construct certain elements in the buildings, such as interior columns, with well-chosen, mostly cylindrical stones being stacked on top of each other and then plastered over. Sometimes, stones were used to build walls up to $70 \mathrm{~cm}$ high around the exterior of the building to protect the base of the building from rain and running water. These materials are often recycled, or left in place, where they become part of the environment (Figure 26).
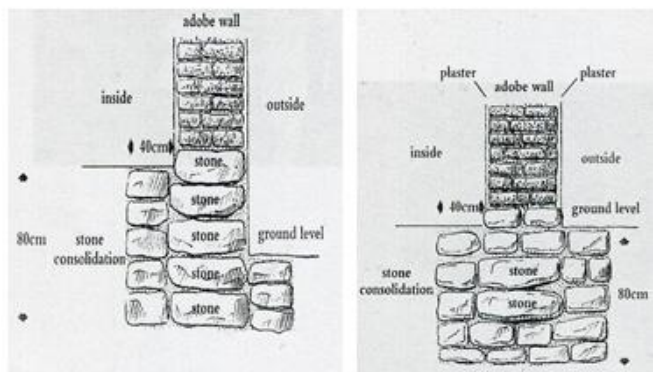

Fig. 26. The use of stones in the foundations of a traditional building, Najd [1]

\section{Conclusions}

\subsection{Results}

-The layout of the streets obeys the contextual requirements of the climate and the cultural needs of the Saudi residents. The streets are narrow and at a human scale, which maintains shadow throughout the day, and the walls are also shaded when grouped in denser developments.

- The social and climatic factors have affected the form of the residential buildings. The houses are arranged in a townhouse layout, with shared walls. Each house is generally arranged around a courtyard, with a main entrance from the street leading to a foyer and a twisted entry to the courtyard, so as to maintain the privacy of the family.

- The exterior walls are thick and heavily tapered, from $100 \mathrm{~cm}$ at the base to $45 \mathrm{~cm}$ at the top. Openings in the walls are generally well situated and small to allow light and ventilation into the interior. The interior of Najdi houses are also decorated with relief work, including geometric designs and organic motifs, such as palm fronds and simple trees shaped like the principal design elements. 


\subsection{Recommendations}

Analysis of the traditional buildings and urban fabric in the central region have allowed certain principles to be identified that can be followed in future residential building designs and urban fabrics in this area.

In the urban design of residential areas, it is necessary to:

- Provide blocks and spaces that provide shade and cool conditions, and return to the harmony of an urban fabric that is suitable for the environment of the urban desert, in order to provide the maximum protection of housing blocks and spaces from solar radiation;

- Have a special urban space for residents for their social communication;

- Reduce the area of large squares to reduce the thermal radiation;

- Increase the height of buildings overlooking such squares, and their adjacent blocks, to avoid the movement of vortex air;

- Appropriately orient the squares, with the shorter side aligned with the direction of the wind to enable the possibility of controlling the wind by changing its direction or reducing its strength through architectural structures or plantings; and

- Choose an appropriate design for the network of roads and corridors in the urban block to control the movement of air and protect against the impacts of undesirable wind movements and dust.

In the design of residential buildings, it is necessary to:

- Return to the style of the inner courtyard, which is the best solution to protect against sand-laden winds in desert areas, and to protect the house from thermal radiation and increase internal shadowed zones;

- Preserve the possibility of allowing large windows in the interior rooms while maintaining the privacy of the family, and reducing the size of external windows;

- Adapt to the surrounding environment and preserve the audio and visual privacy of the family, to align with the teachings of the Islamic religion; and

- Construct housing with natural materials that are located in the central region.

\section{REFERENCES}

[1] AL ALshakh, A., Shira, F., Aljatali, I. and Alhanatal, S. (2010). Architectural heritage of the Kingdom of Saudi Arabia. Ministry of Municipal and Rural Affairs, KSA.

[2] Ishteeaque, E. and Alsaid, F. (2008). The native architecture of Saudi Arabia. King Fahed National Library cataloging-in-Publication Data, Riyadh.

[3] Talib, K. (1984). Shelter in Saudi Arabia. Martin's Press, New York.

[4] Al Nouser, M. (1999). Characteristics of urban heritage in Saudi Arabia (Najed region). Dara Kind Abdel Aziz Press, Riyadh.

[5] El Shawaty, M. (2011). Historical and heritage palaces and houses in the Kingdom of Saudi Arabia. Saudi Commission for Tourism and Antiquities, Riyadh.

[6] Evan, M. (1980). Housing, Climate, Comfort. The Architecture Press, London.

[7] Al-Fagal, K. (2002). Architecture and environment in the hot desert regions. Dar AlThaqafa Publishing, Cairo.

[8] Konya, A. (1984). Design primer for hot climate. The Architectural Press, London.

[9] Al Wakil, S. (1989). Climate and the architecture of hot regions, 3rd edition. The World of the Book Press, Cairo.

[10] Brown, G. (2001). Sun, wind and light, 2nd edition. John Wiley \& Sons Press, New York. 
[11] Hamoda, N. (2002). Solar radiation and architecture in desert areas. Symposium on Urban Development in Desert Areas and Building Problems. Ministry of Public Works and Housing, Kingdom of Saudi Arabia.

[12]Facey, W. (1997). Back to earth: Adobe building in Saudi Arabia. Al Turath, Riyadh.

[13]Alomar, A. (2007). The Traditional Architecture in Najed. Indexing of the King Fahad National Library for Publishing, Riyadh.

[14] Mortada, H. (2016). Sustainable Desert Traditional Architecture of the Central Region of Saudi Arabia, John Wiley \& Sons

[15] Hasanean, H.; Almazroui, M. Rainfall, 2015. Features and Variations over Saudi Arabia, A Review. Climate , 578-626

[16] Qassem Y. Tarawneh, Shakhawat Chowdhury. 2018, Trends of Climate Change in Saudi Arabia: Implications on Water Resources. Climate.

\footnotetext{
دراسة تحليلية للمباني السكنية التراثية في المنطقة الوسطى من المملكة العربية السعودية ملخص البحث:

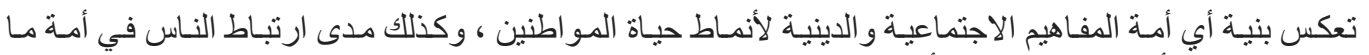

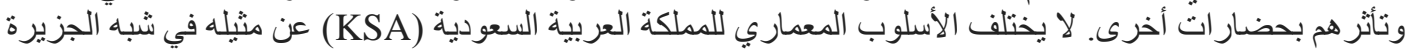

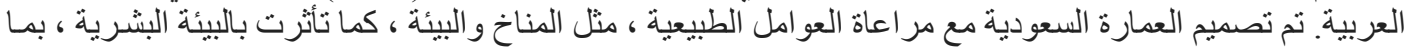

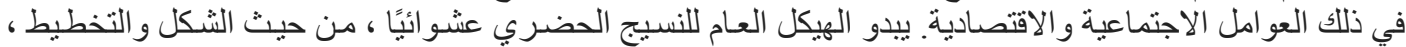

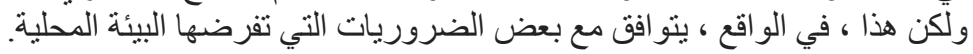

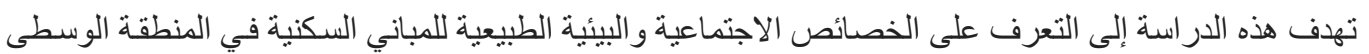

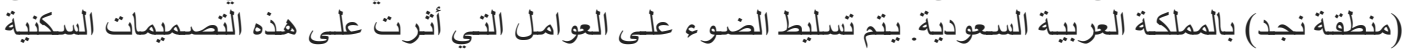

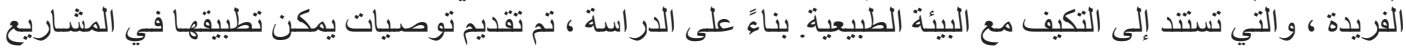
المعمارية المستقبلية في المنطقة. أهداف البحث

تهدف هذه الدر اسة إلى التعرف على الجو انب المعمارية البيئية و الاجتماعية المناخية السعودية التقليديـة ، المستمدة

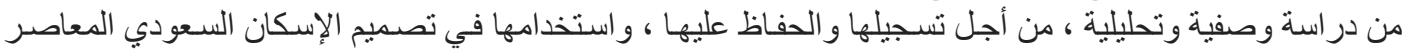

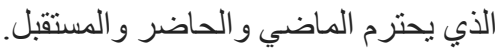
منهجية البحث تضمنت منهجية الدر اسة ثناثة أجز اء: 1. در اسة نظرية ركزت على الخلفية التاريخية للمملكة العربية السعودية ، وكذللك الأنماط العامة للاندسة المعمارية

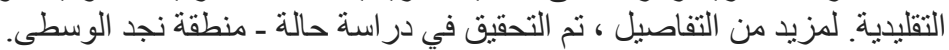

2. تم إجر اء در اسة تحليلية للنسيج و الإسكان الحضري التقليدي ، بناءً على العو امل البيئية الاجتماعية و المناخية.

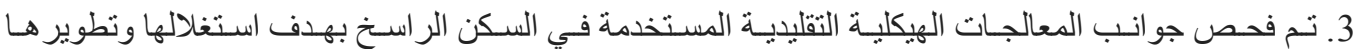

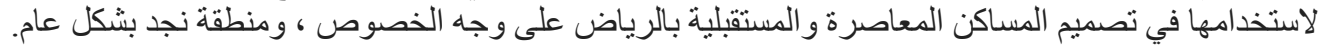

